\title{
Effect of Soil and Foliar Application of Nitrogen on Morpho-Physiological, Growth Characters and Seed Yield of Rapeseed
}

\author{
Lolesh Pegu ${ }^{1 *}$, Perves Ahmed ${ }^{2}$, Britan Rahman $^{3}$, Pompy Deka ${ }^{2}$ and Ranjit Sarma ${ }^{4}$ \\ ${ }^{1}$ Department of Crop Physiology, ${ }^{2}$ Department of Agronomy, ${ }^{3}$ Department of Soil Science, \\ ${ }^{4}$ Department of Horticulture, SCS College of Agriculture, Assam Agricultural University, \\ Dhubri (Assam), India \\ *Corresponding author
}

\section{A B S T R A C T}

\begin{tabular}{|c|}
\hline Keywords \\
\hline $\begin{array}{l}\text { Nitrogen } \\
\text { fertilization, } \\
\text { Chlorophyll, Leaf } \\
\text { area, SLW, Yield } \\
\text { attributes, Rapeseed }\end{array}$ \\
\hline Article Info \\
\hline $\begin{array}{l}\text { Accepted: } \\
12 \text { August } 2020 \\
\text { Available Online: } \\
\text { 10 September } 2020\end{array}$ \\
\hline
\end{tabular}

\section{Introduction}

Rapeseed and mustard is the second most important edible oilseed crop after groundnut in India contributing $28.6 \%$ in the total oilseeds production and shared $27.8 \%$ in the oilseed economy of the country (Shekhawat et al., 2012). In Assam, rapeseed and mustard is mainly grown as Rabi crop and the crop is sown during mid October to mid November.
A research work was conducted at the experimental field of SCS College of Agriculture, Assam Agricultural University, Dhubri, Assam during Rabi season of 2019-2020 to study the "effect of soil and foliar fertilization of nitrogen on morpho-physiological, growth characters and seed yield of rapeseed variety TS-46. The experiment comprised of ten treatments. Results revealed that there were significant differences among the treatments in terms of total leaf chlorophyll content, leaf area per plant, specific leaf weight (SLW), plant height, number of branches per plant, plant dry matter, number of siliquae per plant, number of seeds per siliqua and seed yield. Split application of nitrogen (recommended basal dose + foliar spray) significantly increased the morpho-physiological, growth characters and yield attributing parameters. Amongst all the treatments, $T_{10}$ (Recommended dose of NPK + Foliar spray of $2 \%$ urea at 20 DAS and 40 DAS) proved to be the best followed by $\mathrm{T}_{6}$ (Recommended dose of NPK + Foliar spray of $1 \%$ urea at 20 DAS and 40 DAS) and $T_{9}$ (Recommended dose of NPK + Foliar spray of $2 \%$ urea at 20 DAS). The treatments $\mathrm{T}_{10}, \mathrm{~T}_{6}$ and $\mathrm{T}_{9}$ recorded $57.36 \%, 57.28 \%$ and $52.13 \%$, respectively higher seed yield over $\mathrm{T}_{1}$ (Control i.e. without fertilizers) and $26.65 \%, 26.52 \%$ and $17.65 \%$ respectively over $T_{2}$ (soil application of recommended dose of NPK alone). 
is one of the major elements required for growth and development of the crop plants. It is an important ingredient of various organic compounds such as chlorophyll, nucleic acids, amino acids, proteins, enzymes and hormones (Mingotte et al., 2013). Hence, the efficient use of nitrogen is absolutely essential for higher yield of crop plants. The soil of Assam is acidic in nature (Medhi et al., 2002). Of the total geographical area of Assam, $72.3 \%$ area is degraded acidic soils (with $\mathrm{p}^{\mathrm{H}}<5.5$ ) and $43.1 \%, 52.8 \%$ and $42.1 \%$ are low in available nitrogen, phosphorus and potassium content respectively (Bandypadhyay et al., 2016). Although nitrogenous fertilizer is applied, about $50 \%$ of the fertilizer applied to the crop plant is partially lost through different mechanisms including leaching, volatilization and denitrification (Choudhury and Kennedy, 2005; Sinha et al., 2018). However, such problems can be overcome by applying a portion of plants nutritional need with foliar fertilization. Jamal et al., (2006) reported that the wastage of nutrients can be reduced by foliar applications of dilute solutions of nutrients to supplement the basal applications. Foliar fertilization can result in rapid utilization of nutrients to correct deficiencies that prevail during critical periods of growth. It is also more efficient in terms of absorption as nutrients are not subjected to different losses that occur with soil application. Keeping the above in view, a field experiment was conducted to study the effect of soil and foliar application of nitrogen on morphophysiological, growth characters and seed yield of rapeseed.

\section{Materials and Methods}

The investigation was carried out at the farm of SCS College of Agriculture, Assam Agricultural University, Dhubri, Assam during Rabi season of 2019-2020. Soil samples were collected randomly from 0-15 $\mathrm{cm}$ depth prior to experimentation and estimated for various soil parameters. The soil was acidic $(\mathrm{pH} 5.34)$ in nature with low in available $\mathrm{N}\left(270.12 \mathrm{kgha}^{-1}\right)$, medium in $\mathrm{P}_{2} \mathrm{O}_{5}$ (27.35 $\mathrm{kgha}^{-1}$ ) and $\mathrm{K}_{2} \mathrm{O}$ (235.27 $\mathrm{kgha}^{-1}$ ) content. The experimental design adopted was Randomized Block Design (RBD) with 3 replications. The rapeseed variety TS-46 was selected for the study. The experiments comprised of ten treatments viz. $\mathrm{T}_{1}$ : Control (Without fertilizers), $\mathrm{T}_{2}$ : Recommended dose (RD) of NPK, $\mathrm{T}_{3}$ : Recommended dose of PK + Foliar spray of $1 \%$ urea at 20 days after sowing (DAS), $\mathrm{T}_{4}$ : Recommended dose of PK + Foliar spray of $1 \%$ urea at 20 DAS and 40 DAS, $\mathrm{T}_{5}$ : Recommended dose of NPK + Foliar spray of $1 \%$ urea at 20 DAS, $\mathrm{T}_{6}$ : Recommended dose of NPK + Foliar spray of $1 \%$ urea at 20 DAS and 40 DAS, $\mathrm{T}_{7}$ : Recommended dose of PK + Foliar spray of $2 \%$ urea at $20 \mathrm{DAS}, \mathrm{T}_{8}$ : Recommended dose of PK + Foliar spray of $2 \%$ urea at 20 DAS and 40 DAS, T9: Recommended dose of NPK + Foliar spray of $2 \%$ urea at $20 \mathrm{DAS}, \mathrm{T}_{10}$ : Recommended dose of NPK + Foliar spray of $2 \%$ urea at 20 DAS and 40 DAS. The recommended dose of $\mathrm{N}, \mathrm{P}_{2} \mathrm{O}_{5}(\mathrm{P})$ and $\mathrm{K}_{2} \mathrm{O}$ (K) @ 40:35:15 kg/ha respectively for rapeseed was applied as per the treatment combinations.

Plant height was recorded at physiological maturity stage from the surface of the soil to the apex of the plant and expressed in centimeters. Total number of branches per plant was recorded at harvesting stage. For estimating total plant dry matter at harvest, the previously tagged plants were carefully uprooted from the soil, washed thoroughly under running tap water to remove all kinds of clinging particles from plant parts. Plants were then dried in hot air oven at $70^{\circ} \mathrm{C}$ until the plant material attains a constant weight. Then the dried samples were weighed and weights are expressed in grams. Leaf area was recorded with the help of CI-203 Laser leaf area meter and expressed in square 
centimeters per plant at flowering stage. Specific leaf weight (SLW) is the ratio of total leaf dry weight per unit of leaf area. It was calculated following the method of Radford (1967) at flowering stage and expressed in $\mathrm{mg} \mathrm{cm}^{-2}$.

SLW $=\frac{\text { Total leaf dry weight }}{\text { Area of leaf }}\left(\mathrm{mg} \mathrm{cm}^{-2}\right)$

The total chlorophyll content in leaf tissue were estimated by non-maceration method using Dimethyl Sulphoxide (DMSO) as suggested by Hiscox and Israelstam (1979) using the following formula.

Total chlorophyll $=\left(20.2 \times \mathrm{D}_{645}\right)+(8.02 \mathrm{x}$ $\left.\mathrm{D}_{663}\right) \times(\mathrm{V} / 1000 \times \mathrm{W}) \mathrm{mg} \mathrm{g}^{-1} \mathrm{fwt}$

Where,

$\mathrm{D}_{645}=$ Absorbance at $645 \mathrm{~nm}$

$\mathrm{D}_{663}=$ Absorbance at $663 \mathrm{~nm}$

$\mathrm{V}=$ Volume of DMSO in $\mathrm{ml}$

$\mathrm{W}=$ Fresh weight of sample taken in $\mathrm{g}$

Total number of siliquae per plant at harvest was recorded from already tagged plants from each plot. Number of seeds per siliqua was recorded from tagged plants. The seed obtained from each plot after threshing, cleaning and sun drying were weighed and the seed yield per hectare was calculated and expressed in kilograms per hectare. The data were statistically analyzed (Sahu and Das, 2014) and results are discussed below.

\section{Results and Discussion}

\section{Morpho-physiological characters}

Significant difference was observed among the nitrogen fertilizer treatments in terms of total leaf chlorophyll content, leaf area per plant and specific leaf weight (Table 1). Total leaf chlorophyll content was found to be highest in the treatment $\mathrm{T}_{10}$ (RD of NPK + Foliar spray of $2 \%$ urea at 20 DAS and 40 DAS) followed by $\mathrm{T}_{6}$ (RD of NPK + Foliar spray of $1 \%$ urea at 20 DAS and 40 DAS) and $\mathrm{T}_{9}$ (RD of NPK + Foliar spray of $2 \%$ urea at 20 DAS). Chlorophylls are green pigments that reflect the plant photosynthetic capacity. Green leaf area is considered to be one of the photosynthetic determinants in crop plants (Kaur et al., 2015). Crop growth depends on adequate formation of leaf area for efficient interception of light (Wilson, 1981). Leaf area per plant differed significantly among the treatments. The treatment $\mathrm{T}_{10}$ (RD of NPK + Foliar spray of $2 \%$ urea at 20 DAS and 40 DAS) recorded the highest value followed by $\mathrm{T}_{6}$ (RD of NPK + Foliar spray of $1 \%$ urea at 20 DAS and 40 DAS) and $\mathrm{T}_{9}$ (RD of NPK + Foliar spray of $2 \%$ urea at 20 DAS). Leaf thickness is expressed as specific leaf weight. Specific leaf weight refers to dry mass of tissue per unit leaf area. Thicker leaves would have more number of mesophyll cells with high density of chlorophyll and therefore, have a greater photosynthetic capacity than thinner leaves (Craufurd et al., 1999). Thick leaves are associated with high yielding capacities of mung bean and mash bean cultivars were reported by Sharma (2015). Specific leaf weight, a measure of thickness of leaf, has been reported to have a strong positive correlation with leaf photosynthesis in soybean as reported by Bowes et al., (1972).

The treatments differed significantly in terms of specific leaf weight in the present study. Highest value for specific leaf weight was observed in $\mathrm{T}_{6}$ (RD of NPK + Foliar spray of $1 \%$ urea at $20 \mathrm{DAS}$ and $40 \mathrm{DAS}$ ) followed by $\mathrm{T}_{10}$ (RD of NPK + Foliar spray of $2 \%$ urea at 20 DAS and 40 DAS) and T $_{9}$ (RD of NPK + Foliar spray of $2 \%$ urea at 20 DAS). The treatments $\mathrm{T}_{10}$ and $\mathrm{T}_{9}$ were statistically at par with $\mathrm{T}_{6}$ in terms of specific leaf weight. 
Table.1 Effect of soil and foliar application of nitrogen on morpho-physiological and growth characters of rapeseed

\begin{tabular}{|c|c|c|c|c|c|c|}
\hline \multirow[t]{2}{*}{ Treatment } & \multicolumn{3}{|c|}{ Morpho-physiological characters } & \multicolumn{3}{|c|}{ Growth characters } \\
\hline & $\begin{array}{c}\text { Total leaf } \\
\text { chlorophyll } \\
\left(\mathrm{mgg}^{-1} \text { fw }\right)\end{array}$ & $\begin{array}{c}\text { Leaf area } \\
\left(\mathrm{cm}^{2} \text { plant }^{-1}\right)\end{array}$ & $\begin{array}{c}\text { Specific leaf } \\
\text { weight } \\
\left(\mathrm{mgcm}^{-2}\right)\end{array}$ & $\begin{array}{c}\text { Plant height } \\
\text { (cm) }\end{array}$ & $\begin{array}{c}\text { Number of } \\
\text { Branches } \\
\text { per plant }\end{array}$ & $\begin{array}{l}\text { Total plant } \\
\text { dry matter } \\
\left(\text { g plant }^{-1}\right)\end{array}$ \\
\hline$T_{1}:$ Control (Without fertilizers) & 2.87 & 300.75 & 3.33 & 49.22 & 4.00 & 7.38 \\
\hline$T_{2}:$ RD of NPK & 4.31 & 435.86 & 4.47 & 59.99 & 6.60 & 10.73 \\
\hline $\mathrm{T}_{3}:$ RD of PK + Foliar spray of $1 \%$ urea at $20 \mathrm{DAS}$ & 3.45 & 311.03 & 3.76 & 57.89 & 5.80 & 9.27 \\
\hline $\mathrm{T}_{4}:$ RD of PK + Foliar spray of $1 \%$ urea at 20 DAS and 40 DAS & 4.10 & 323.98 & 3.94 & 59.47 & 6.07 & 9.87 \\
\hline$T_{5}:$ RD of NPK + Foliar spray of $1 \%$ urea at 20 DAS & 4.75 & 445.55 & 4.68 & 69.85 & 8.20 & 11.54 \\
\hline$T_{6}:$ RD of NPK + Foliar spray of $1 \%$ urea at 20 DAS and 40 DAS & 5.11 & 449.96 & 5.96 & 67.80 & 8.60 & 13.27 \\
\hline$T_{7}:$ RD of PK + Foliar spray of $2 \%$ urea at 20 DAS & 3.66 & 316.73 & 3.69 & 58.73 & 5.47 & 9.51 \\
\hline $\mathrm{T}_{8}:$ RD of PK + Foliar spray of $2 \%$ urea at 20 DAS and 40 DAS & 3.98 & 428.18 & 4.12 & 60.12 & 5.47 & 10.05 \\
\hline$T_{9}:$ RD of NPK + Foliar spray of $2 \%$ urea at 20 DAS & 4.87 & 446.43 & 4.77 & 67.73 & 8.27 & 11.61 \\
\hline$T_{10}:$ RD of NPK + Foliar spray of $2 \%$ urea at 20 DAS and 40 DAS & 5.23 & 451.25 & 5.41 & 68.79 & 8.53 & 14.01 \\
\hline SEm \pm & 0.351 & 6.951 & 0.367 & 2.533 & 0.696 & 0.754 \\
\hline CD $(5 \%)$ & 1.051 & 20.811 & 1.100 & 7.585 & 2.083 & 2.257 \\
\hline
\end{tabular}

Table.2 Effect of soil and foliar application of nitrogen on yield attributing parameters and seed yield of rapeseed

\begin{tabular}{|c|c|c|c|}
\hline Treatment & $\begin{array}{c}\text { Number of siliquae } \\
\text { per plant }\end{array}$ & $\begin{array}{c}\text { Number of seeds } \\
\text { per siliqua }\end{array}$ & $\begin{array}{c}\text { Seed yield } \\
\left(\mathrm{kg} \mathrm{ha}^{-1}\right)\end{array}$ \\
\hline $\mathbf{T}_{1}:$ Control (Without fertilizers) & 63.27 & 13.07 & 306.60 \\
\hline$T_{2}:$ RD of NPK & 90.13 & 16.47 & 527.40 \\
\hline $\mathrm{T}_{3}:$ RD of PK + Foliar spray of $1 \%$ urea at 20 DAS & 74.40 & 15.20 & 350.70 \\
\hline $\mathrm{T}_{4}:$ RD of PK + Foliar spray of $1 \%$ urea at 20 DAS and 40 DAS & 80.60 & 16.13 & 415.80 \\
\hline $\mathrm{T}_{5}:$ RD of NPK + Foliar spray of $1 \%$ urea at 20 DAS & 93.67 & 17.00 & 630.00 \\
\hline$T_{6}:$ RD of NPK + Foliar spray of $1 \%$ urea at 20 DAS and 40 DAS & 102.13 & 18.73 & 717.84 \\
\hline $\mathrm{T}_{7}:$ RD of PK + Foliar spray of $2 \%$ urea at 20 DAS & 76.80 & 16.60 & 405.70 \\
\hline $\mathrm{T}_{8}:$ RD of PK + Foliar spray of $2 \%$ urea at 20 DAS and 40 DAS & 85.00 & 16.87 & 464.10 \\
\hline$T_{9}:$ RD of NPK + Foliar spray of $2 \%$ urea at 20 DAS & 94.20 & 17.47 & 640.50 \\
\hline $\mathrm{T}_{10}:$ RD of NPK + Foliar spray of $2 \%$ urea at 20 DAS and 40 DAS & 104.80 & 18.30 & 719.06 \\
\hline SEm \pm & 3.595 & 0.884 & 8.299 \\
\hline CD $(5 \%)$ & 10.763 & 2.648 & 24.848 \\
\hline
\end{tabular}


Split application of nitrogen (recommended basal dose + foliar spray) registered higher values for total leaf chlorophyll content, leaf area per plant and specific leaf weight compared to that of control and soil application alone. Nitrogen is an essential component of many metabolically important compounds viz. chlorophyll, amino acids, proteins and nucleic acids (Jamal et al., 2006). The lower values for these parameters with soil application of NPK alone over split fertilization might be due to unavailability of some portion of soil applied nitrogen to plant due to leaching losses, volatilization and denitrification. Dejoux et al., (2003) reported that up to $50 \%$ of the applied nitrogen may be lost through leaching, decomposition and volatilization. However, the loss of nutrients can be reduced by foliar applications of dilute solutions of nutrients to supplement the basal applications (Jamal et al., 2006). Foliar application is also more efficient in terms of absorption as nutrients are not subjected to different losses that occur with soil application. Siddiqui et al., (2008) reported that soil and foliar application of nutrients improved the performance of rapeseedmustard genotypes with respect to growth characteristics and physico-biochemical parameters.

\section{Growth Characters}

The growth characters viz. plant height, number of branches per plant and total plant dry matter differed significantly due to different nitrogen treatments (Table 1). Among all the treatments, the treatment $\mathrm{T}_{5}$ (RD of NPK + Foliar spray of $1 \%$ urea at 20 DAS) showed the highest value for plant height followed by $\mathrm{T}_{10}$ (RD of NPK + Foliar spray of $2 \%$ urea at 20 DAS and 40 DAS) and $\mathrm{T}_{6}$ (RD of NPK + Foliar spray of $1 \%$ urea at 20 DAS and 40 DAS). Highest number of branches per plant was observed in the treatment $\mathrm{T}_{6}(\mathrm{RD}$ of NPK + Foliar spray of
$1 \%$ urea at 20 DAS and 40 DAS) followed by $\mathrm{T}_{10}$ (RD of NPK + Foliar spray of $2 \%$ urea at 20 DAS and 40 DAS) and $T_{9}$ (RD of NPK + Foliar spray of $2 \%$ urea at 20 DAS). In terms of total plant dry matter, the treatment $\mathrm{T}_{10}$ (RD of NPK + Foliar spray of $2 \%$ urea at 20 DAS and 40 DAS) registered the highest value followed by $\mathrm{T}_{6}$ (RD of NPK + Foliar spray of $1 \%$ urea at $20 \mathrm{DAS}$ and $40 \mathrm{DAS}$ ) and $\mathrm{T}_{9}$ (RD of NPK + Foliar spray of $2 \%$ urea at 20 DAS).

In the present study, the recommended basal dose of nitrogen along with foliar spray significantly increased the plant height, number of branches per plant and total plant dry matter over control and soil application of NPK alone. Foliar nutrition is a more economic way to supplement the plants' nutrients for more efficient utilization (Girma et al., 2007). During critical stages of plant growth foliar fertilization with nitrogen can directly deliver the nutrient to the plant tissues. The higher values for these parameters with split fertilization might be due to the efficiency in utilization of nitrogen for photosynthesis, cell division, cell enlargement and tissue and organ formation as nitrogen is an essential component of many metabolically important compounds viz. chlorophyll, amino acids, proteins and nucleic acids. Sinha et al., (2018) reported that soil plus foliar application of nitrogen improves plant height, number of branches per plant and dry matter accumulation in mustard.

\section{Yield attributes and seed yield}

The yield attributes viz. number of siliquae per plant, number of seeds per siliqua and seed yield differed significantly due to different nitrogen treatments (Table 2). In terms of number of siliquae per plant, the treatment $\mathrm{T}_{10}$ (RD of NPK + Foliar spray of $2 \%$ urea at 20 DAS and 40 DAS) recorded the highest value followed by $\mathrm{T}_{6}$ (RD of NPK + 
Foliar spray of $1 \%$ urea at 20 DAS and 40 DAS) and $\mathrm{T}_{9}$ (RD of NPK + Foliar spray of $2 \%$ urea at $20 \mathrm{DAS})$. The highest number of seeds per siliqua was found in the treatment $\mathrm{T}_{6}$ (RD of NPK + Foliar spray of $1 \%$ urea at 20 DAS and 40 DAS) followed by $\mathrm{T}_{10}$ (RD of NPK + Foliar spray of $2 \%$ urea at 20 DAS and 40 DAS) and $\mathrm{T}_{9}$ (RD of NPK + Foliar spray of $2 \%$ urea at 20 DAS). Out of all treatments, the highest seed yield was recorded in the treatment $\mathrm{T}_{10}$ (RD of NPK + Foliar spray of $2 \%$ urea at 20 DAS and 40 DAS) followed by $\mathrm{T}_{6}$ (RD of NPK + Foliar spray of $1 \%$ urea at 20 DAS and 40 DAS) and $\mathrm{T}_{9}$ (RD of NPK + Foliar spray of $2 \%$ urea at 20 DAS).

Among all the treatments, the treatment $T_{10}$ registered the highest seed yield which might be due to highest number of siliquae per plant in that treatment. The treatment $\mathrm{T}_{6}$ although recorded the highest value for seeds per siliqua could not registered highest seed yield which might be due to lower number of siliquae per plant. However, the seed yield in the treatment $\mathrm{T}_{6}$ was found to be statistically at par with $\mathrm{T}_{10}$. Siddiqui et al., (2008) reported that soil and foliar application of nitrogen improved siliquae number per plant, seeds number per siliqua, 1000-seed weight, seed yield per hectare, oil content, and oil yield per hectare and fatty acid composition in oil of rapeseed-mustard genotypes. Jamal et $a l .$, (2006) also reported that the grain yield of wheat increased when NPK was applied both through soil and foliar sprays.

From the present investigation it can be concluded that both soil and foliar application of nitrogen improved overall performance of the rapeseed in respect to morphophysiological, growth as well yield attributes and seed yield. Application of recommended dose of NPK as basal along with spraying of $2 \%$ urea at 20 DAS and 40 DAS was found to be the best amongst the nitrogen treatments under rainfed condition of Dhubri district of Assam.

\section{References}

Anonymous (2017-18). Economic Survey of Assam: Transformation and Development Department. Directorate of Economics \& Statistics, Government of Assam. pp 90

Anonymous (2017-18). Economic Survey of India. Directorate of Economics \& Statistics, Department of Agriculture, Cooperation \& Farmers Welfare, Government of India. Volume-2, Chapter-07, pp 101

Bandypadhyay, S., Ray, P., and Ray, S.K. (2016) Present Status and Future Strategies to Maintain the Soil Health in the North East India (Souvenir Article for the National Seminar on Bringing Second Green Revolution in North East India). National Bureau of Soil Survey and Land Use Planning (ICAR), Jorhat - 7850 04, India

Bowes, G.W., Orgen, L., and Hageman, R.H. (1972). Light saturated photosynthesis rate, RuBP carboxylase activity and specific leaf weight in soybeans grown under different light intensities. Crop Science 12: 77-79

Choudhury, A.T.M.A. and Kennedy, I.R. (2005). Nitrogen Fertilizer Losses from Rice Soils and Control of Environmental Pollution Problems. Communications in Soil Science and Plant Analysis 36: 1625-1639

Craufurd, P.C., Wheeler. T.R., Ellis, R.H., Summer, R.J. and Williams, J.H. (1999). Effect of temperature and water deficit on water use efficiency, carbon isotope discrimination and specific leaf area in peanut. Crop Science 39: 136-142

Dejoux, J.F., Meynard, J.M., Reab, R., Rochec, R. and Saulasa, P. (2003). Evaluation of Environmentally Friendly Crop Management Systems Based on Very Early Sowing Dates for Winter Oilseed Rape in France. Agronomie 30: 725-736 
Girma, K., Martin, K.L., Freeman, K.W., Mosali, J., Teal, R.K., Raun, W.R., Moges, S.M. and Arnall, D.B. (2007). Determination of Optimum Rate and Growth for Foliar Applied Phosphorus in Corn. Communications in Soil Science and Plant Analysis 38: 1137-1154

Hiscox, J.D. and Israelstam, G.F. (1979). A Method for the Extraction of Chlorophyll from Leaf Tissue Without Maceration. Canadian Journal of Botany 57: 13321334

Jamal, Z., Hamayun, M., Ahmad, N. and Chaudhary, M.F. (2006). Effects of Soil and Foliar Application of Different Concentrations of NPK and Foliar Application of $\left(\mathrm{NH}_{4}\right)_{2} \mathrm{SO}_{4}$ on Different Yield Parameters in Wheat. Journal of Agronomy 5: 251-256

Kaur, G., Ghai, N., Kaur, J. and Singh, S. (2015). Growth efficiency and yield of pigeonpea (Cajanuscajan L.) as affected by foliar application of mineral nutrients. Journal of Plant Science and Research 2: 130

Medhi, B.K., Deka, C.R., Chakravarty, D.N., Talukdar, A. and Hazarika, S. (2002). An Appraisal of Nature of Soil Activity, Chemical and Electrochemical Characterization of Some Ultisols and Alfisols of Kamrup District of Assam. Research on Cros. 3: 54-60

Mingotte, F.L.C., Hanashiro, R.K. and Filho, D.F. (2013). Response of Rice Cultivars to Nitrogen in Upland Conditions. Revista Ceres 60: 86-95

Radford, P.J. (1967). Growth Analysis Formulae-their Use and Abuse. Crop
Science

171-175

Sahu, P.K. and Das, A.K. (2014). Agriculture and Applied Statistics-II. Kalyani Publishers, New Delhi-110002, pp 170174

Sharma, P. (2015). Growth dynamics and leaf characteristics of pulse under water deficit and irrigation regimes. Annals of Plant and Soil Research 17: 150-155

Shekhawat, K., Rathore, S.S., Premi, O.P., Kandpal, B.K. and Chauhan, J.S. (2012). Advances in Agronomic Management of Indian Mustard (Brassica juncea (L.) Czernj. Cosson): An Overview. International Journal of Agronomy 2012: 1-14

Siddiqui, M.H., Mohammad, F., Khan, M.N. and Khan, M.M.A. (2008). Cumulative Effect of Soil and Foliar Application of Nitrogen, Phosphorus, and Sulfur on Growth, Physico-Biochemical Parameters, Yield Attributes, and Fatty Acid Composition in Oil of Erucic AcidFree Rapeseed-Mustard Genotypes. Journal of Plant Nutrition 31: 1284-1298

Sinha, R., Negi, M.S., Mahapatra, B.S. and Shukla, A. (2018). Managing Nitrogen Requirements through Foliar Application of Nitrogen in Mustard (Brassica juncea L. Czernj. and Cosson.). International Journal of Current Microbiology and Applied Sciences. 7: 3761-3768

Wilson, J. (1981). Analysis of light interception by single plant. Annals of Botany 48: 501-505

\section{How to cite this article:}

Lolesh Pegu, Perves Ahmed, Britan Rahman, Pompy Deka and Ranjit Sarma. 2020. Effect of Soil and Foliar Application of Nitrogen on Morpho-physiological, Growth Characters and Seed Yield of Rapeseed. Int.J.Curr.Microbiol.App.Sci. 9(09): 1434-1440.

doi: https://doi.org/10.20546/ijcmas.2020.909.182 